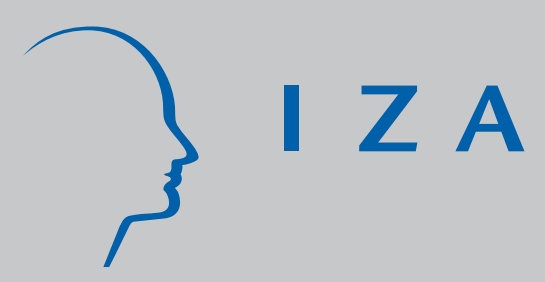

IZA DP No. 3171

On the Inverse Relationship between Unemployment and Absenteeism: Evidence from Natural Experiments and Worker Heterogeneity

René Fahr

Bernd Frick

November 2007 


\title{
On the Inverse Relationship between Unemployment and Absenteeism: Evidence from Natural Experiments and Worker Heterogeneity
}

\author{
René Fahr \\ University of Cologne \\ and IZA \\ Bernd Frick \\ University of Paderborn \\ and IAAEG
}

\section{Discussion Paper No. 3171 \\ November 2007}

\author{
IZA \\ P.O. Box 7240 \\ 53072 Bonn \\ Germany
}

Phone: +49-228-3894-0
Fax: +49-228-3894-180
E-mail: iza@iza.org

Any opinions expressed here are those of the author(s) and not those of the institute. Research disseminated by IZA may include views on policy, but the institute itself takes no institutional policy positions.

The Institute for the Study of Labor (IZA) in Bonn is a local and virtual international research center and a place of communication between science, politics and business. IZA is an independent nonprofit company supported by Deutsche Post World Net. The center is associated with the University of Bonn and offers a stimulating research environment through its research networks, research support, and visitors and doctoral programs. IZA engages in (i) original and internationally competitive research in all fields of labor economics, (ii) development of policy concepts, and (iii) dissemination of research results and concepts to the interested public.

IZA Discussion Papers often represent preliminary work and are circulated to encourage discussion. Citation of such a paper should account for its provisional character. A revised version may be available directly from the author. 
IZA Discussion Paper No. 3171

November 2007

\section{ABSTRACT}

\section{On the Inverse Relationship between Unemployment and Absenteeism: Evidence from Natural Experiments and Worker Heterogeneity ${ }^{*}$}

Although an inverse relationship between sickness absence and unemployment has been documented in a number of studies using either quarterly or annual data from different countries with varying institutional frameworks, it is not yet clear whether this empirical regularity is due to changes in the individual costs of absence when unemployment increases (incentive effect) or, alternatively, to changes in the composition of the workforce over the business cycle (selection effect). In order to provide evidence to evaluate the relative importance of both effects we first investigate the effects of changes in the unemployment benefit entitlement system with monthly absence data for East and West Germany for the years 1991-2004. Second, we analyze the impact of differences in the costs of unemployment on the annual absence rates of workers in different sickness insurance funds using state-level annual absence rates for the years 1993-2004. We find clear evidence in favor of an incentive effect.

JEL Classification: J63, K31, M51

Keywords: absenteeism, unemployment, selection effect, incentive effect, natural experiment

Corresponding author:

René Fahr

Department of Business Administration

University of Cologne

Albertus-Magnus-Platz

D-50923 Cologne

Germany

E-mail: rene.fahr@uni-koeln.de

\footnotetext{
* We thank Tim Barmby, Henning Lohmann and Øivind Nielsen for helpful comments. We are also grateful for comments by participants at the Workshop in Personnel Economics 2006 in Zurich and in seminar presentations at IZA, the University of Cologne, and RWI, Essen. Any remaining errors and omissions are, of course, our own.
} 


\section{Introduction}

An inverse relationship between sickness absence and unemployment has been documented in a number of studies using either quarterly or annual data from different countries with varying institutional frameworks. Examples are, among others, Audas and Goddard (2001), Doherty (1979), Kenyon and Dawkins (1989), and Leigh (1985). Evidence for Germany is provided by Schnabel (1991), Schnabel and Stephan (1993), Thalmaier (1999), and Boss (2000). More recently, two cross-country comparisons of the determinants of sickness absence have been published by Barmby et al. (2002) as well as Frick and Malo (forthcoming). However, it is not yet clear whether this empirical regularity is due to changes in the individual costs of absence when unemployment increases (we call this the "moral hazard effect”) or, alternatively, to changes in the composition of the workforce over the business cycle because workers with health problems are the first to lose their jobs in a recession (we call this the "selection effect"). ${ }^{1}$

The identification of the source of the inverse relationship between sickness absence and unemployment has important implications for labor market policy as well as for the personnel policies of firms. If the relationship were mainly the result of worker moral hazard, managers should consider increasing their monitoring activities depending on the costs of absenteeism to the firm (see Coles and Treble 1996). Another reaction could be to stimulate mutual monitoring by introducing team incentives (see the evidence reported in Knez and Simester 2001). Although the decisions of policy makers largely depend on the welfare function they are trying to maximize, detection of the dominance of an incentive effect implies a less generous system of sick pay as well as less generous unemployment insurance. Dominance of the selection effect, on the other hand, indicates inefficiencies on the side of firms, since absence rates differ between booms and downturns. For policy makers dominance of the selection effect implies implementing a less restrictive system of employment protection legislation.

Using two hitherto unavailable data sets from official health insurance statistics, the paper aims to provide evidence on the relative importance of the "incentive hypothesis" against the "selection hypothesis” as an explanation for the relationship between unemployment and absenteeism. Monthly time series for the unemployment rate and the absence rate in East and West Germany enable us to distinguish between the two effects. Analyzing changes in the coverage of dismissal protection legislation allows us to assess the importance of selection effects while analyzing changes in the maximum duration of unemployment benefit entitlements allows us to as-

1 Brown and Sessions (1996) summarize a number of theoretical models and review the evidence that was available until the mid 1990s. 
sess the importance of incentive effects. A second data source provides annual data at the level of the 16 federal states of Germany on the unemployment and the absence rate. We use absence figures for three different types of sickness insurance funds that are characterized by marked differences in the socio-economic structure of their members. In particular, the costs of unemployment are likely to differ significantly between the three populations. Thus, exploiting the heterogeneity between the three populations allows us to investigate the importance of the incentive effect in the unemployment-absenteeism relation.

Our empirical strategy to disentangle selection from incentive effects relies on nontestable identifying assumptions. While this is still unsatisfactory from the perspective of a clear identification of selection versus incentive effects we are confident that the two different empirical approaches used in the present paper provide important additional insights into the sources of the unemployment-absenteeism relation. This is of particular importance as the available literature provides no completely convincing approach to distinguish between selection and incentive effects in explaining the unemployment-absenteeism relation. This shortcoming is, in turn, mainly due to the lack of appropriate data (see below).

The relationship between unemployment and absenteeism has been investigated with individual as well as with aggregate data. In principle, longitudinal information on individual employees would be the most appropriate data to investigate this relationship: First, health status and health hazards at the workplace have been shown to be an important determinant of absence behavior (Allen 1991 and Leigh 1991). Second, psycho-social factors at the workplace (Bourbonnais et al. 2005) as well as personality (Judge et al. 1997 and Daviri and Woods 2006) have also been shown to be influential determinants of individual absence behavior. However, longitudinal data on individual workers very often has either no information on the individuals' health status or on workplace characteristics (as in Askildsen et al. 2005). Moreover, individual level data are typically not available on a monthly basis, resulting in very little cyclical variation and making identification difficult. Empirical testing of microeconomic models with aggregate data usually comes at the cost that the findings cannot be directly attributed to changes in individual behavior as suggested by economic theory. As we will demonstrate, this turns out as a particular problem when investigating what we call the "selection effect". However, we are confident that our approach is suitable to detect incentive effects in aggregate data. Evidence on incentive effects that can be found in aggregate data is certainly more compelling than evidence found in individual level data, because the persistence of these effects in aggregate data demonstrates the economic significance of these effects. Given the limitations associated to the currently available individual level data in terms of time frequency and the information available we are confident 
that the aggregate information we use in the present paper is the best data source that is presently available.

Two recent papers address the same question as we do. ${ }^{2}$ The paper closest to ours is Arai and Thoursie (2005). They analyze quarterly data on unemployment and absence rates aggregated by region and industry for Sweden. Since employment protection legislation in Sweden is as restrictive as in Germany they use information on the type of employment contracts. In particular, Arai and Thoursie (2005) argue that the correlation between the percentage of temporary workers in a region and/or industry and the absence rate allows separating the selection and the incentive effect discussed above. Their results suggest that the incentive effect clearly dominates. In their analysis, however, identification of the selection effect hinges on the assumption that the percentage of workers on temporary contracts is a valid proxy for marginal workers.

Askildsen et al. (2005) use a six-year panel of individual-level register data covering a $10 \%$ random sample of the Norwegian labor force. The size of the sample notwithstanding, their data is problematic insofar as only sickness spells are reported that lasted longer than 14 days. This, in turn, is likely to lead to a considerable under-representation of cases of "voluntary absenteeism”. Restricting their sample to the continuously employed workers and estimating a fixed effects logit model, Askildsen et al. (2005) find that the probability of long term sickness absence is significantly higher when unemployment is low. They interpret this result as suggesting that selection effects cannot explain the inverse relationship between unemployment and absenteeism. However, the restriction to longer spells of sickness absence excludes most of what can be termed "voluntary sickness". Moreover, since the data used in their study covers only a period of six years the identification of the selection effect is at best suggestive.

Without being able to disentangle selection and incentive effects, some papers have provided notable evidence on the importance of the incentive effect. Riphahn and Thalmaier (2001), for example, use individual-level panel data for Germany and find a large and statistically significant increase in the predicted probability of a work absence following the end of the probation period for recently hired employees. This finding clearly suggests a moral hazard explanation for worker absenteeism. Using daily absence data from individual social security records over a period of two years, Johansson and Palme (2002) find that in Sweden the costs of being absent significantly affect work absence behavior. The variation in the costs of being absent in their paper was due to a legislative change for short term sickness benefits.

2 Additional evidence on this topic is provided by a case study using absence data for a sample of 150 employees from a single German medium-sized industrial company over the period of 10 years in Kauermann and Ortlieb (2004). They find no evidence in favor of a selection effect in the sense that employees who are absent more frequently are more likely to be laid off in a downturn. However, they find some kind of incentive effect in the sense that employees who are to be laid off are more frequently absent before leaving the company. 
The paper proceeds as follows: Section 2 outlines the theoretical background on the role of unemployment as an incentive device in employment relationships. Section 3 offers a description of the data and the empirical strategy, section 4 presents the results and section 5 concludes.

\section{Incentives and Selection in Employment Relationships: The Role of Unemployment}

The two competing hypotheses concerning the relationship between unemployment and absenteeism can be summarized as follows: First, since worker absenteeism is disruptive to the production process, firms have an incentive to monitor absentees and to punish "voluntary" absenteeism as "shirking”. As argued by Askildsen et al. (2005) this “voluntary” absenteeism needs not be restricted to absence spells that do not require medical certificates. Within the framework of the physician agency theory (see McGuire 2000), physicians issue medical certificates as agents for their patients. Since the true medical condition of the patient is often unobservable to the doctor, he or she may agree to issue or extend the duration of a medical certificate on demand. Any penalty will serve to increase the expected costs of absence faced by the employee (see Brown and Sessions 1996). Voluntary absence is more likely to occur in the presence of legal regulations that stipulate workers to be remunerated whilst absent. Drago and Wooden (1992) and Frick and Malo (forthcoming) provide evidence that generous sick leave entitlements are associated with higher rates of absence. However, moral hazard that may follow from such a complete insurance system may be completely offset by unemployment. The rationale is that higher unemployment rates make the employment relation comparatively more valuable to the employee as the expected costs of being dismissed increase. Shapiro and Stiglitz (1984) for example have convincingly argued that unemployment may serve as a functional equivalent to monitoring, acting as a "worker discipline device”. This argument is formalized in Barmby et al. (1994) where higher costs of unemployment induced by less benevolent unemployment benefits and/or an expected longer duration of unemployment following dismissal reduce the "efficiency wage" which is necessary to reduce shirking.

Second, the hiring and firing behavior of firms is likely to lead to changes in the composition of the workforce which, in turn, induces changes in the level of absenteeism: in a boom period, firms try to hire the most productive (and least absence-prone) workers first while in a recession they try to dismiss the least productive (and most absence-prone) workers first. Thus, over the business cycle, the risk of being fired should be highest for workers with either an above average number of sickness spells or a particularly long duration of these spells (see Hesselius 
forthcoming). Following this argument, the unemployment rate is taken as a proxy for the business cycle which triggers the behavior of firms. However, the hiring and firing behavior of firms might be dampened by rigorous dismissal legislation. Moreover, we can think of a composition effect going the other way round. In particular, in an upturn firms might have to rely on more absence prone marginal workers because there is not enough supply of reliable and productive workers. ${ }^{3}$ We will argue below that the particular nature of our data allows us to distinguish the former from the latter type of composition effect.

\section{Data and Econometric Approach}

Both data sets contain information on the unemployment and the absenteeism rate, however with different frequencies (monthly and annual, respectively). The annual series are further disaggregated by federal states $(n=16)$ and sickness insurance funds $(n=3)$. The time series on registered unemployment comes from the Federal Employment Agency (Bundesagentur für Arbeit, BA) while the time series on absenteeism comes from the Federal Ministry of Health. ${ }^{4}$ The absence rate is defined as the number of mandatory members of the compulsory health insurance system ("gesetzliche Krankenversicherung”) calling in sick with a medical certificate of work incapability as a percentage of all mandatory members of the compulsory health insurance (excluding (early) retirees, students, youngsters, disabled persons, artists, people doing military or community service, and full-time farmers). ${ }^{5}$

The first data set contains data on the monthly absence and unemployment rates for a 14-year-period (January 1991-December 2004 for West Germany and April 1991-December 2004 for East Germany) resulting in 168 and 165 observations, respectively. ${ }^{6}$ In order to eliminate any spurious seasonal variation that might affect our results, we adjust each series by regressing it on a full set of month dummies and preserving the residuals. The times series on the absence rate and the unemployment rate show a different pattern in West and East Germany during the period of observation. Since we are not particularly interested in the differences in the unemployment-absenteeism relationship between West and East Germany we analyze the data

3 We are grateful to Tim Barmby for pointing this out to us.

4 Detailed statistics including the time series used in the present paper are downloadable at the homepage of the Federal Ministry of Health (www.bmg.bund.de)

5 Medical certificates are issued by physicians and are compulsory for sickness spells longer than three days in a row and require notification of the worker's health insurance fund. Unemployed workers are also obliged to hand in a medical certificate to the employment agency if they are sick longer than three days.

6 Absence rates are either calculated for the first day of every month (in the high-frequency monthly data set) or as annual averages (in the low-frequency yearly data set). 
for both regions separately. This allows us to avoid imposing any constraints on the coefficients. We conduct Granger causality tests to investigate whether the causality goes from unemployment to absenteeism and not vice versa.

\section{Changes in dismissal protection as natural experiments}

With the monthly time series data we use changes in legislation as "natural experiments” to learn more about the relative importance of selection and incentive effects. In particular, we use changes in the exemption threshold in the "Protection against Dismissal Act" (PADA) to find empirical evidence on the importance of selection effects and changes in the maximum duration of unemployment benefit entitlements to find out more about the importance of incentive effects in explaining the unemployment-absenteeism relation.

While some general rules concerning dismissals are provided in the German Civil Code more stringent constraints on dismissals are regulated in the PADA which applies only to businesses employing more than a certain minimum number of workers. The PADA stipulates that an employment relationship can be terminated only if one of the following conditions is fulfilled: (i) dismissal on grounds of personal incapability or health problems, (ii) dismissal on grounds of bad conduct and (iii) redundancy in which case the employer is obliged to adhere to specific social selection criteria. Dismissals on grounds of “voluntary absenteeism” (i.e. staying away from work without being sick) can be justified with either the first or the second reason above. It is, however, rather difficult for German employers to prove that all the requirements for a legally justified dismissal have been met. Therefore, many dismissals are settled either in court or, even more often, out of court resulting in a termination of the employment relationship in return for a severance payment. Even if the employee wins a dismissal case, German labor courts typically dissolve the employment relationship and decide that the employee has to be financially compensated for the loss of job. Essentially, the PADA does not operate as a barrier to dismissals but as a mechanism to ensure financial compensation for the dismissed.

During our period of investigation we observe three changes in PADA legislation. In October 1996 the center-right government under Chancellor Kohl deregulated employment protection by increasing the traditional threshold below which PADA regulations do not apply from five to 10 employees. By the time the new regulations were introduced about $30 \%$ of all establishments, representing $75 \%$ of all employees paying social insurance contributions, were operating under the provisions of the PADA. The more generous exemption policy made dismissals easier in about $10 \%$ of all German establishments, representing about $5 \%$ of the workforce (Bau- 
(Bauer et al. forthcoming). The new regulation became effective only for new hires, all other workers were guaranteed the original level of protection for three more years. In January 1999 the newly appointed center-left government under Chancellor Schröder re-introduced the old exemption threshold of five full-time equivalent employees. In January 2004, the barrier was again increased to 10 employees with the incumbent employees retaining their more generous level of employment protection (see Figure 1 for a summary of these policy changes).

Because it is easier for employers to dismiss workers not covered by the PADA, we expect to see fewer dismissals of marginal workers (i.e. those with high rates of sickness absence) in times of high unemployment when the exemption threshold of PADA is at 10 employees. To identify such a selection effect we construct indicator variables for the periods in which the respective exemption threshold is in effect. Admittedly, the inclusion of unemployed workers in the calculation of the absence rate might hinder a proper identification of selection effects since firing marginal workers should not affect the absence rate significantly. However, as long as higher dismissal rates induce individuals to leave the labor force (which might be particularly the case for older workers or for women) it should still be possible to get hints about selection effects by changes in the exemption thresholds of PADA. It is now quite plausible to assume that any marginal workers hired in times of a boom due to the lack of supply of highly productive workers (the second type of composition effect) are unemployed persons. Together with the assumption that at least part of the dismissed individuals leaves the labor force, the inclusion of unemployed in the pool of individuals for whom we observe the absence rate might even help us to separate selection effects from other composition effects over the course of the business cycle. An additional problem in the identification of selection effects with the higher PADA exemption threshold during period PADA 1 (see Figure 1) arises from the fact that during that period workers calling in sick received only 80 percent of their regular pay. While this should, in principle, provide an additional incentive not to report sick "voluntarily", the potential effect was offset by the fact that most collective agreements guaranteed full payments in case of sickness irrespective of the change in legislation (Thalmaier 1999). Accordingly, the incentive effect of this change is likely to be negligible.

Any incentive effect from unemployment will be stronger if the replacement rate in case of unemployment or the duration of the entitlement period is less generous. During our period of investigation, we observe a change in the maximum entitlement period for older workers. In April 1997, the entitlement period for employees aged 42 and 43 was reduced from 18 to 12 months, for employees aged 44 to 48 from 22 to 16 months, for those aged 49 to 53 from 26 to 21 months and for employees older than 53 the maximum length of unemployment benefits was 
reduced from 32 to 28 months. An incentive effect will be identified by a negative coefficient of the interaction between a dummy indicating the period after April 1997 and the unemployment rate.

Figure 1

Overview of Policy Changes

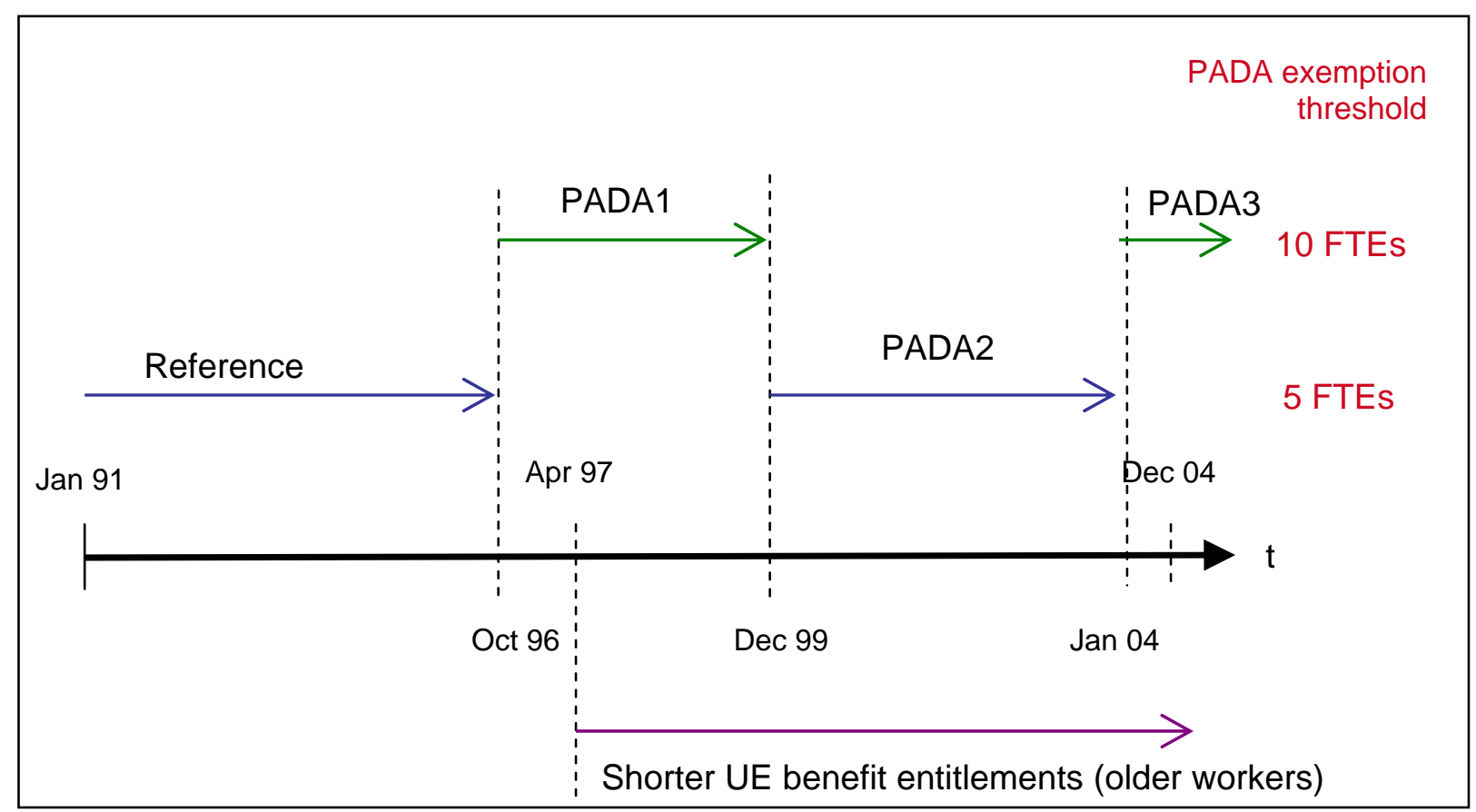

A selection effect driven by the business cycle might not be properly identified by the unemployment rate. Because employers decide more on the grounds of expectations we additionally control for the business cycle as reflected in the "business-expectation-index" of the ifo Institute for Economic Research (ifo-index R3) ${ }^{7}$.

Using longitudinal data might lead to spurious regression results if the data are nonstationary. One problem is that standard unit root tests have low power in time series with structural breaks. Even tests which can account for structural breaks in the data are able to account for only one such break. We test the absence rate and the unemployment rate with a modified Dickey Fuller test (DF GLS test) for unit-root and with a Kwiatkowski, Phillips, Schmidt, Shin (1992)Test for the null of stationarity. To account for structural breaks we repeat the test for different time spans in the data. When using first differences of the variables of interest we can reject the null of co-integration but cannot reject the null of stationarity (detailed results are available from the authors upon request).

7 Time series are available at http://www.cesifo-group.de. 
According to the co-integration tests, we estimate the following equation with first differences of the absence rate as our dependent variable for West and East Germany separately with and without the full set of month dummies:

$$
\begin{aligned}
\Delta \mathrm{AR}_{\mathrm{t}}=\beta_{0}+ & \beta_{1} \Delta \mathrm{UR}_{\mathrm{t}}+\beta_{2} \mathrm{IFO}_{\mathrm{t}}+\beta_{3} \mathrm{PADA}_{\mathrm{t}}+\beta_{4} \mathrm{PADA}_{\mathrm{t}}+\beta_{5} \mathrm{PADA}_{\mathrm{t}}+\beta_{6} \mathrm{UISHORT}_{\mathrm{t}} \\
& +\beta_{7} \mathrm{PADA}_{\mathrm{t}} \mathrm{x} \Delta \mathrm{UR}_{\mathrm{t}}+\beta_{8} \mathrm{PADA}_{\mathrm{t}} \mathrm{x} \Delta \mathrm{UR}_{\mathrm{t}}+\beta_{9} \mathrm{PADA}_{\mathrm{t}} \mathrm{x} \Delta \mathrm{UR}_{\mathrm{t}}+ \\
& +\beta_{10} \mathrm{UISHORT}_{\mathrm{t}} \mathrm{x} \Delta \mathrm{UR}_{\mathrm{t}}+\varepsilon_{i t}
\end{aligned}
$$

where we allow for serially autocorrelated disturbances of order 1 of the form $\varepsilon_{i t}=\rho \varepsilon_{i t}-1+\zeta_{i t}$, where $\rho<1$ and $\zeta \sim \mathrm{N}\left(0, \sigma_{\zeta}^{2}\right)$. A change in the monthly adjusted absence rate and unemployment rate is denoted by $\Delta \mathrm{AR}_{\mathrm{t}}$ and $\Delta \mathrm{UR}_{\mathrm{t}}$, respectively. $\mathrm{IFO}_{\mathrm{t}}$ denotes the IFO-Business-Expectations Index (R3), PADA1 $1_{\mathrm{t}}$ : is a dummy variable indicating the period October 1996 - December 1999 with an exemption threshold of PADA of 10 FTEs, PADA2 $2_{t}$ indicates the period January 1999 December 2003 with an exemption threshold of 5 FTEs and PADA3 $3_{t}$ indicates the period after January 2004 with an exemption threshold of 10 FTEs. Finally, the variable UISHORT repre- $_{\mathrm{t}}$ sents the period after April 1997 where the maximum duration of unemployment benefits had been significantly reduced for older unemployed persons.

Following the discussion above, we consider the following coefficients as evidence in favor of a selection effect:

$$
\beta_{7}<0 \text { and } \beta_{9}<0 .
$$

Incentive effects seem to be an important explanation for the observed data patterns if

$$
\beta_{10}<0 \text {. }
$$

Using worker heterogeneity to evaluate the importance of shirking effects

Our second approach allows the identification of incentive effects by using heterogeneity in the absence rates reported by different types of sickness insurance funds. Due to historical development, several different insurance funds continue to coexist. Until 1996, the choice of the insurance fund has been to a certain extent compulsory. ${ }^{8}$ Starting in 1996, workers have the choice to move between insurance funds. Nevertheless, the majority retain membership in their

8 Detailed information on the compulsory insurance funds system in Germany can be found at http://www.bpb.de/wissen/Z0NG5T,0,Gesetzliche Krankenkassen und ihre Mitglieder.html accessed on $2^{\text {nd }}$ November 2007 (in German). The information provided in the following paragraphs follows the description in this document. 
formerly compulsory insurance fund. We have annual absence data from the 16 federal states for a period of 12 years (1993-2004) for three different types of sickness insurance funds: "AOK” for "regular", mostly unqualified blue-collar workers, "BKK” for blue-collar workers in large firms and "IKK" for qualified craftsmen mostly in small and medium-sized firms ${ }^{9}$. Out of 70.3 million insured persons (not only paid employees, but also their dependent family members) 36\% are in the AOK, $21 \%$ in the $\mathrm{BKK}$ and $6 \%$ in the IKK. The remaining persons (mainly whitecollar workers) are members of so-called "substitute sickness insurance societies” (Ersatzkassen). The percentage of workers who are insured in the BKK has almost doubled since 1996 while the AOK have lost about $10 \%$ of their members. As the content of the insurance contracts is regulated by law, the different types of insurances offer the same access to physicians and the same quality of services. Insurance contributions differ slightly between the different insurance funds. The AOK have the highest contributions since their members are on average older and face higher health hazards. This fact is accounted for by a (highly contested) risk structure compensation scheme. Most of these risks, however, are contributed by people who do not account for the calculation of the absenteeism rate (mostly retired persons and children).

The expectation is that the regional unemployment rate has a more pronounced influence on the absence rates of less qualified blue-collar workers (“AOK”-type insurance) than on either workers in large firms (primarily members of a "BKK" sickness insurance fund) or on craftsmen (mostly members of an "IKK"-type sickness insurance fund). The reasoning is that monitoring costs increase with firm size and that therefore workers in large firms have a significantly lower risk of being dismissed due to shirking. Craftsmen, on the other hand, have a high probability of finding a new job rather soon even in a situation of high unemployment because of the transferable skills they have accumulated during their apprenticeships.

If the unfavorable risk structure in the AOK is also accounted for by a higher percentage of marginal workers, we will nevertheless be able to find evidence in favor of incentive effects if dismissed workers remain in the pool of unemployed workers rather than exiting the labor force. If, on the other hand, a considerable percentage of the dismissed marginal workers exit the labor force (i.e. if our analysis of the first data set provides evidence consistent with selection effects), then a more pronounced influence of the regional unemployment rate on the absence rates of AOK members is due to a combination of incentive and selection effects.

9 Barmby et al. (2004) show that firm size has a positive and statistically significant impact on individual absenteeism: Other things equal, the absence rate in small firms (1-10 employees) is 1.5 percentage points lower than in large firms (50 and more employees). In medium sized firms (11-49 employees) the difference is about 0.7 percentage points lower. 
To exclude spurious results we test all series in the panel data for the hypothesis that the absence and the unemployment rates are stationary against the alternative hypothesis that at least one series has a unit root with a version of Hadri's (2000) test. Testing the null of stationarity is more appropriate in the current context than testing the null of unit roots in all series, since a rejection of the latter does not necessarily mean that the entire panel is stationary, while a rejection of the former would indicate potential for spurious results at least in some series. While the test has low power given the rather small number of observations, the results suggest that the use of differences in the core specification excludes spurious findings. In our preferred specification we estimate equation (2) without and with year dummies to capture potential time effects.

$$
\begin{aligned}
\Delta \mathrm{AR}_{\mathrm{it}}= & \gamma_{0}+\gamma_{1} \Delta \mathrm{UR}_{\mathrm{it}}+\beta \gamma_{2} \mathrm{BKK}_{\mathrm{t}}+\gamma_{3} \mathrm{IKK}_{\mathrm{it}}+ \\
& \gamma_{4} \mathrm{BKK}_{\mathrm{it}} \mathrm{x} \Delta \mathrm{UR}_{\mathrm{it}}+\gamma_{5} \mathrm{IKK}_{\mathrm{it}} \mathrm{x} \Delta \mathrm{UR}_{\mathrm{it}}+\lambda_{i}+\varepsilon_{i t}
\end{aligned}
$$

where $\lambda_{i}$ reflects a federal state fixed effect, $\varepsilon_{i t}$ a random disturbance and $\Delta \mathrm{AR}_{\mathrm{t}}$ denotes a change in the annual average of the absence rate, $\Delta \mathrm{UR}_{\mathrm{t}}$ a change in the annual average of the unemployment rate. Indicator variables for the type of sickness insurance fund are denoted by $\mathrm{BKK}_{\mathrm{t}}$ and $\mathrm{IKK}_{\mathrm{t}}$. With the AOK sickness insurance fund as the reference group we test the following hypothesis to identify an incentive effect

$$
\gamma_{4}>0 \text { and } \gamma_{5}>0
$$

in case we cannot find evidence in support of hypothesis H1. Otherwise, hypothesis H3 reflects a mixture of selection and incentive effects.

\section{Results}

Table 1 presents the results for West Germany. Our major hypothesis is tested by the interaction of the various period dummies for different PADA regimes and a dummy for the shorter benefit entitlement period. We do not observe a negative relation between the change in the unemployment rate and the change in the absence rate. However, there is a significantly negative effect of the change in the absence rate during the first period, when the PADA exemption threshold is 10 employees. This effect disappears in the two way fixed effects specification (column (6)). We expect a negative effect for the interaction between PADA regimes 1 and 3 and the change in the unemployment rate if selection effects matter. In fact we find a weakly significant positive effect for the interaction with PADA regime 1 . The total effect of the period following 
the first PADA modification on the change in the absence rate in the specification without month dummies is also positive.

Table 1

Monthly Unemployment Rate and Absenteeism in West Germany, 1991-2004

\begin{tabular}{|c|c|c|c|c|c|c|}
\hline & $(1)$ & $(2)$ & (3) & (4) & $(5)$ & (6) \\
\hline Dependent variable: & \multicolumn{6}{|c|}{ change in absence rate } \\
\hline $\begin{array}{l}\text { change in unemployment } \\
\text { rate }\end{array}$ & $\begin{array}{l}-0.141 \\
{[0.440]}\end{array}$ & $\begin{array}{l}-0.034 \\
{[0.517]}\end{array}$ & $\begin{array}{l}-0.062 \\
{[0.521]}\end{array}$ & $\begin{array}{l}0.001 \\
{[0.538]}\end{array}$ & $\begin{array}{l}-0.033 \\
{[0.827]}\end{array}$ & $\begin{array}{l}-0.119 \\
{[0.833]}\end{array}$ \\
\hline $\begin{array}{l}\text { IFO Business Expectations } \\
\text { Index }(2000=1, R 3)\end{array}$ & $\begin{array}{l}0 \\
{[0.001]}\end{array}$ & $\begin{array}{l}0 \\
{[0.002]}\end{array}$ & $\begin{array}{l}0 \\
{[0.001]}\end{array}$ & $\begin{array}{l}0 \\
{[0.002]}\end{array}$ & $\begin{array}{l}0.001 \\
{[0.001]}\end{array}$ & $\begin{array}{l}0 \\
{[0.002]}\end{array}$ \\
\hline $\begin{array}{l}\text { PADA regime } 1 \text { (10 FTEs, } \\
\text { new hirees) }\end{array}$ & & & $\begin{array}{l}-0.02 \\
{[0.019]}\end{array}$ & $\begin{array}{c}-0.009 \\
{[0.035]} \\
\end{array}$ & $\begin{array}{l}-0.038^{\star \star} \\
{[0.019]}\end{array}$ & $\begin{array}{l}-0.027 \\
{[0.036]} \\
\end{array}$ \\
\hline PADA regime 2 (5 FTEs) & & & $\begin{array}{l}-0.024 \\
{[0.025]}\end{array}$ & $\begin{array}{l}-0.015 \\
{[0.041]}\end{array}$ & $\begin{array}{l}-0.033 \\
{[0.028]}\end{array}$ & $\begin{array}{c}-0.031 \\
{[0.040]}\end{array}$ \\
\hline $\begin{array}{l}\text { PADA regime } 3 \text { (10 FTEs, } \\
\text { new hirees) }\end{array}$ & & & $\begin{array}{c}-0.023 \\
{[0.029]} \\
\end{array}$ & $\begin{array}{c}-0.012 \\
{[0.041]} \\
\end{array}$ & $\begin{array}{l}-0.028 \\
{[0.032]} \\
\end{array}$ & $\begin{array}{c}-0.024 \\
{[0.042]} \\
\end{array}$ \\
\hline $\begin{array}{l}\text { Shorter UI entitlement } \\
\text { period }\end{array}$ & & & $\begin{array}{l}0.024 \\
{[0.023]}\end{array}$ & $\begin{array}{l}0.016 \\
{[0.028]}\end{array}$ & $\begin{array}{l}0.033 \\
{[0.023]}\end{array}$ & $\begin{array}{l}0.032 \\
{[0.026]}\end{array}$ \\
\hline $\begin{array}{l}\text { PADA regime } 1 \times \text { ch. in } \\
\text { unemployment rate }\end{array}$ & & & & & $\begin{array}{l}1.624^{*} \\
{[0.918]}\end{array}$ & $\begin{array}{l}1.692^{*} \\
{[0.912]}\end{array}$ \\
\hline $\begin{array}{l}\text { PADA regime } 2 \times \text { ch. in } \\
\text { unemployment rate }\end{array}$ & & & & & $\begin{array}{l}3.810^{\star} \\
{[2.231]}\end{array}$ & $\begin{array}{l}4.564^{\star *} \\
{[2.284]}\end{array}$ \\
\hline $\begin{array}{l}\text { PADA regime } 3 \times \text { ch. in } \\
\text { unemployment rate }\end{array}$ & & & & & $\begin{array}{l}2.554 \\
{[3.491]} \\
\end{array}$ & $\begin{array}{l}3.241 \\
{[3.586]} \\
\end{array}$ \\
\hline $\begin{array}{l}\text { UI benefit change } x \text { ch. in } \\
\text { unemployment rate }\end{array}$ & & & & & $\begin{array}{l}-3.684^{\star} \\
{[1.991]} \\
\end{array}$ & $\begin{array}{l}-4.059 * * \\
{[1.968]}\end{array}$ \\
\hline Constant & $\begin{array}{l}-0.029 \\
{[0.113]} \\
\end{array}$ & $\begin{array}{l}0.019 \\
{[0.181]}\end{array}$ & $\begin{array}{l}-0.038 \\
{[0.124]}\end{array}$ & $\begin{array}{l}0.015 \\
{[0.187]}\end{array}$ & $\begin{array}{c}-0.052 \\
{[0.132]} \\
\end{array}$ & $\begin{array}{l}0.015 \\
{[0.199]}\end{array}$ \\
\hline Month dummies & no & yes & no & yes & no & yes \\
\hline Observations & 167 & 167 & 167 & 167 & 167 & 167 \\
\hline R-squared & 0 & 0.01 & 0.01 & 0.01 & 0.02 & 0.03 \\
\hline $\begin{array}{l}\text { Implied overall effect of } \\
\text { change in unemployment } \\
\text { rate }\end{array}$ & & & & & & \\
\hline Reference period ( 5 FTE) & & & & & -0.033 & -0.119 \\
\hline PADA 1 (10 FTEs) & & & & & 1.591 & 1.573 \\
\hline PADA 2 (5 FTEs) & & & & & 3.777 & 4.445 \\
\hline PADA 3 (10 FTEs) & & & & & 2.521 & 3.122 \\
\hline UI benefit entitlements long & & & & & -0.033 & -0.119 \\
\hline $\begin{array}{l}\text { UI benefit entitlements } \\
\text { short }\end{array}$ & & & & & -3.717 & -4.178 \\
\hline
\end{tabular}


Moreover, we find a significant positive effect for the influence of the change in the unemployment rate on the change in the absence rate for the period of PADA regime 2. This is surprising insofar as the exemption threshold here is identical to the one in the reference period.

Table 2

Monthly Unemployment Rate and Absenteeism in East Germany, 1991-2004

\begin{tabular}{|c|c|c|c|c|c|c|}
\hline & (1) & (2) & (3) & (4) & (5) & (6) \\
\hline Dependent variable & \multicolumn{6}{|c|}{ change in absenteeism rate } \\
\hline $\begin{array}{l}\text { change in unemployment } \\
\text { rate }\end{array}$ & $\begin{array}{l}-0.292 \\
{[0.512]}\end{array}$ & $\begin{array}{l}-0.23 \\
{[0.498]}\end{array}$ & $\begin{array}{l}-0.264 \\
{[0.526]}\end{array}$ & $\begin{array}{l}-0.214 \\
{[0.506]}\end{array}$ & $\begin{array}{l}-0.355 \\
{[0.789]}\end{array}$ & $\begin{array}{l}-0.251 \\
{[0.745]}\end{array}$ \\
\hline $\begin{array}{l}\text { IFO Business Expectations } \\
\text { Index }(2000=1, R 3)\end{array}$ & $\begin{array}{c}-0.001 \\
{[0.001]}\end{array}$ & $\begin{array}{l}-0.001 \\
{[0.002]}\end{array}$ & $\begin{array}{c}-0.001 \\
{[0.001]}\end{array}$ & $\begin{array}{l}-0.001 \\
{[0.002]}\end{array}$ & $\begin{array}{c}-0.001 \\
{[0.002]}\end{array}$ & $\begin{array}{l}-0.001 \\
{[0.002]}\end{array}$ \\
\hline $\begin{array}{l}\text { PADA regime } 1 \text { (10 FTEs, } \\
\text { new hires) }\end{array}$ & & & $\begin{array}{l}-0.02 \\
{[0.027]} \\
\end{array}$ & $\begin{array}{c}-0.015 \\
{[0.039]} \\
\end{array}$ & $\begin{array}{l}-0.051^{* *} \\
{[0.020]}\end{array}$ & $\begin{array}{l}-0.036 \\
{[0.038]} \\
\end{array}$ \\
\hline PADA regime 2 (5 FTEs) & & & $\begin{array}{l}-0.025 \\
{[0.032]}\end{array}$ & $\begin{array}{l}0.016 \\
{[0.061]}\end{array}$ & $\begin{array}{l}-0.056^{* *} \\
{[0.028]}\end{array}$ & $\begin{array}{l}-0.027 \\
{[0.057]}\end{array}$ \\
\hline $\begin{array}{l}\text { PADA regime } 3 \text { (10 FTEs, } \\
\text { new hires) }\end{array}$ & & & $\begin{array}{l}-0.018 \\
{[0.035]}\end{array}$ & $\begin{array}{l}0.029 \\
{[0.060]}\end{array}$ & $\begin{array}{c}-0.047 \\
{[0.032]}\end{array}$ & $\begin{array}{l}-0.012 \\
{[0.056]}\end{array}$ \\
\hline $\begin{array}{l}\text { Shorter UI entitlement } \\
\text { period }\end{array}$ & & & $\begin{array}{l}0.023 \\
{[0.028]}\end{array}$ & $\begin{array}{l}0.016 \\
{[0.032]}\end{array}$ & $\begin{array}{l}0.053^{\star *} \\
{[0.024]}\end{array}$ & $\begin{array}{l}0.058^{\star \star} \\
{[0.025]}\end{array}$ \\
\hline $\begin{array}{l}\text { PADA regime } 1 \times \text { change in } \\
\text { unemployment rate }\end{array}$ & & & & & $\begin{array}{l}1.34 \\
{[0.815]}\end{array}$ & $\begin{array}{l}1.202 \\
{[0.760]}\end{array}$ \\
\hline $\begin{array}{l}\text { PADA regime } 2 \times \text { change in } \\
\text { unemployment rate }\end{array}$ & & & & & $\begin{array}{l}1.415 \\
{[1.442]}\end{array}$ & $\begin{array}{l}1.559 \\
{[1.512]}\end{array}$ \\
\hline $\begin{array}{l}\text { PADA regime } 3 \times \text { change } \\
\text { in unemployment rate }\end{array}$ & & & & & $\begin{array}{l}1.084 \\
{[2.050]}\end{array}$ & $\begin{array}{l}1.287 \\
{[2.129]}\end{array}$ \\
\hline $\begin{array}{l}\text { Ul benefit change } x \text { change } \\
\text { in unemployment rate }\end{array}$ & & & & & $\begin{array}{l}-1.338 \\
{[0.906]}\end{array}$ & $\begin{array}{l}-1.57 \\
{[0.950]}\end{array}$ \\
\hline Constant & $\begin{array}{l}0.065 \\
{[0.128]}\end{array}$ & $\begin{array}{l}0.075 \\
{[0.204]}\end{array}$ & $\begin{array}{l}0.068 \\
{[0.139]}\end{array}$ & $\begin{array}{l}0.07 \\
{[0.211]}\end{array}$ & $\begin{array}{l}0.069 \\
{[0.143]}\end{array}$ & $\begin{array}{l}0.079 \\
{[0.219]}\end{array}$ \\
\hline month dummies & no & yes & no & yes & no & yes \\
\hline Observations & 164 & 164 & 164 & 164 & 164 & 164 \\
\hline R-squared & 0.01 & 0.04 & 0.01 & 0.04 & 0.02 & 0.05 \\
\hline $\begin{array}{l}\text { Implied overall effect of } \\
\text { change in unemployment } \\
\text { rate }\end{array}$ & & & & & & \\
\hline Reference period (5 FTE) & & & & & -0.355 & -0.251 \\
\hline PADA 1 (10 FTEs) & & & & & 0.985 & 0.951 \\
\hline PADA 2 (5 FTEs) & & & & & 1.06 & 1.308 \\
\hline PADA 3 (10 FTEs) & & & & & 0.729 & 1.036 \\
\hline UI benefit entitlements long & & & & & -0.355 & -0.251 \\
\hline $\begin{array}{l}\text { UI benefit entitlements } \\
\text { short }\end{array}$ & & & & & -1.693 & -1.821 \\
\hline
\end{tabular}


Probably other effects had an impact on individual behavior in the period right after the new centre-left government had been appointed. One possible explanation is that the new legislation stipulates that sickness payments are $100 \%$ of a worker's regular wage. Although most of the collective bargaining agreements also stipulate a complete replacement of foregone earnings (see our discussion above), many workers might not have been aware of that fact.

The coefficient of the interaction term between PADA 2 and the unemployment rate is insignificantly positive with a positive total effect. Thus, we cannot reject the null hypothesis that the coefficient of the interactions of the indicators for PADA regimes with high exemption levels and the unemployment rate is zero in favor of hypothesis H1. We have to admit that the fact that only new hires are affected by the change in the PADA regimes might make it difficult to identify any effects on absenteeism from firing marginal workers. Moreover, the fact that dismissed worker might still remain in the pool of unemployed workers and contribute to the absence rate might blur the identification of selections effects with the PADA-regime dummies. The unemployment rate has a negative effect on the absence rate following the introduction of a new policy regime where older workers are eligible for unemployment benefits only for shorter periods of time, thus providing clear evidence in favor of H2. The incentive effect of unemployment matters. Similarly to the results for West Germany we find no evidence for the relevance of selection effects in the unemployment-absenteeism relation in the results for East Germany (see Table 2). We find a significantly increasing effect on the absence rate after the introduction of a shorter duration of unemployment benefits. The negative effect of the interaction of the length of unemployment benefits and the change in the unemployment rate on the change in the absence rate is imprecisely measured. Accordingly, we do not find support for hypotheses H1 and H2 in East Germany.

Table 3 presents the results with the panel data for East and West Germany. We find a significantly negative influence of the unemployment rate on the absence rate. An increase in the unemployment rate by one percent leads to a significant decrease in the absence rate of about 0.4 percent in the OLS regression as well as in the state fixed effects specification and a still economically significant decrease of 0.24 percent in the two-way fixed effects specification. The coefficients for the insurance fund dummies and the interactions of the dummies with the unemployment rate are of comparable size in all three specifications. Importantly, the interaction between the change of the unemployment rate and the dummy for workers in the BKK insurance funds as well as the respective interaction with the IKK insurance funds is significantly positive (recall that the reference group - AOK insurance funds - mainly consists of low skilled workers in small and medium sized firms who presumably face higher opportunity costs of losing their 
jobs than workers in larger firms and/or workers with transferable skills and qualifications). Thus we are able to reject the null hypothesis in favor of hypothesis H3. Along with the lack of support for hypothesis $\mathrm{H} 1$ in the monthly data, we take this as clear evidence in favor of an incentive effect of unemployment.

\section{Table 3}

Annual Absenteeism and Unemployment in the Federal States of Germany, 1993-2004

\begin{tabular}{|c|c|c|c|}
\hline & (1) & (2) & (3) \\
\hline & OLS & \multicolumn{2}{|c|}{ Federal State Fixed Effects Model } \\
\hline Dependent variable & \multicolumn{3}{|c|}{ change in absence rate (yearly average) } \\
\hline $\begin{array}{l}\text { change in unemploy- } \\
\text { ment rate (yearly aver- } \\
\text { age) }\end{array}$ & $\begin{array}{l}-0.406^{\star * *} \\
{[0.029]}\end{array}$ & $\begin{array}{l}-0.421^{\star * *} \\
{[0.056]}\end{array}$ & $\begin{array}{l}-0.244^{\star \star \star} \\
{[0.064]}\end{array}$ \\
\hline $\begin{array}{l}\text { BKK unemployment } \\
\text { insurance }(1 / 0)\end{array}$ & $\begin{array}{l}-0.092^{* * *} \\
{[0.025]}\end{array}$ & $\begin{array}{l}-0.092 \\
{[0.065]}\end{array}$ & $\begin{array}{l}-0.092 \\
{[0.059]}\end{array}$ \\
\hline $\begin{array}{l}\text { IKK unemployment } \\
\text { insurance }(1 / 0)\end{array}$ & $\begin{array}{l}0.057^{\star * *} \\
{[0.019]}\end{array}$ & $\begin{array}{l}0.058 \\
{[0.066]}\end{array}$ & $\begin{array}{l}0.058 \\
{[0.060]}\end{array}$ \\
\hline $\begin{array}{l}\text { Interaction BKK x } \\
\text { change in unemploy- } \\
\text { ment rate }\end{array}$ & $\begin{array}{l}0.162^{\star *} \\
{[0.068]}\end{array}$ & $\begin{array}{l}0.162^{\star *} \\
{[0.079]}\end{array}$ & $\begin{array}{l}0.162^{\star *} \\
{[0.071]}\end{array}$ \\
\hline $\begin{array}{l}\text { Interaction IKK x } \\
\text { change in unemploy- } \\
\text { ment rate }\end{array}$ & $\begin{array}{l}0.178^{\star \star \star} \\
{[0.042]}\end{array}$ & $\begin{array}{l}0.178^{\star *} \\
{[0.079]}\end{array}$ & $\begin{array}{l}0.179^{\star *} \\
{[0.072]}\end{array}$ \\
\hline Constant & $\begin{array}{l}-0.031 \\
{[0.019]}\end{array}$ & $\begin{array}{l}-0.028 \\
{[0.046]}\end{array}$ & $\begin{array}{l}-0.603^{\star \star *} \\
{[0.105]}\end{array}$ \\
\hline Year dummies & no & no & yes \\
\hline Observations & 521 & 521 & 521 \\
\hline R-squared & 0.16 & 0.17 & 0.33 \\
\hline Number of states & & 16 & 16 \\
\hline $\begin{array}{l}\text { Implied overall effects o } \\
\text { change in unemploy- } \\
\text { ment rate for }\end{array}$ & & & \\
\hline AOK members & -0.406 & -0.421 & -0.244 \\
\hline BKK members & -0.244 & -0.259 & -0.082 \\
\hline IKK members & -0.228 & -0.243 & -0.065 \\
\hline
\end{tabular}

When evaluating the total effect of unemployment on absenteeism we still find a negative impact for BKK and IKK insurance fund members. The negative elasticity between unemployment and absenteeism goes down to 0.082 and 0.065 for workers in the BKK and IKK, respectively, according to the results of the two-way fixed effects specification. These effects are small, however, compared to the negative elasticity of -0.244 for AOK members. 


\section{Conclusion}

Summarizing, the evidence clearly supports an incentive effect as an explanation for the inverse relation between unemployment and absenteeism: Workers seem to react immediately to changes in the unemployment rate. Moreover, workers with rather poor exit options (i.e. those with the highest opportunity costs of losing their jobs) are the ones who adjust their behavior much faster to changes in the labor market. However, while we are confident that our approach provides convincing evidence in favor of incentive effects, further research is required to provide additional evidence on the role of selection effects in the unemployment-absenteeism relation. Given the presented evidence, it seems that selection effects are of minor importance when compared to incentive effects.

Clearly, the opportunity costs of not going to work are critical: If they are too low, individuals will be tempted to shirk and if they are too high, individuals may choose to attend work even when their health suggests they should absent themselves. However, firms need to be careful when setting the "authorized” sickness level (Brown and Sessions 2004), because low levels of absence are not always preferable. The historical low level of sickness absence in Germany in 2005 - the overall percentage of days missed due to sickness went down to 3.3\% - may already be indicative of a new problem: In a number of recent opinion polls conducted by various sickness insurance funds, around $70 \%$ of German workers report that in the past few months they went to work although they felt sick. However, only about $27 \%$ of all German firms that dismissed parts of their workforce in 2003 report a decrease of absenteeism in the following year while $42 \%$ report a constant sickness rate (Buck 2006). Moreover, in many firms with a shrinking workforce only the number of short-term sickness spells decreases, while the number of longterm absences increases. The net effect can well be a higher absence rate. Thus, although firms are in the short run likely to benefit from what may be termed an "improved work morale", the long-run costs of such changes in individual behavior (in terms of chronically illnesses and reduced loyalty) may be very high.

\section{Literature}

Akerlof, G. A. and J. Yellen (1984): Efficiency Wage Models of the Labor Market. Cambridge: Cambridge University Press.

Allen S. G. (1981): An Empirical Model of Worker Attendance. Review of Economics and Statistics, 71, 1-17. 
Arai, M. and P.S. Thoursie (2005): Incentives and Selection in Cyclical Absenteeism. Labor Economics, 12, 269-280.

Askildsen, J. E., E. Bratberg and O.A. Nielsen (2005): Unemployment, Labor Force Composition and Sickness Absence: A Panel Data Study. Health Economics, 14, 1087-1101.

Audas, R. and J. Goddard (2001): Absenteeism, Seasonality and the Business Cycle. Journal of Economics and Business, 53, 405-419.

Barmby, T., J. Sessions and J. Treble (1994): Absenteeism, Efficiency Wages and Shirking. Scandinavian Journal of Economics, 94, 561-566.

Barmby T., M. Ercolani and J. Treble (2002): Sickness Absence: An International Comparison. Economic Journal, 112, F315-F331.

Barmby, T., M. Ercolani and J. Treble (2004): Sickness Absence in the UK 1984-2002. Swedish Economic Policy Review, 11, 65-88.

Bauer, T., S. Bender and H. Bonin (forthcoming): Dismissal Protection and Worker Flows in Small Establishments, Economica.

Bourbonnais, R. et al. (2005): Psychosocial Work Environment and Certified Sick Leave among Nurses during Organizational Changes and Downsizing. Industrial Relations / Relations Industrielles, 60, 483-509.

Boss, A. (2000): Lohnfortzahlung und Krankenstand. Zeitschrift für Wirtschaftspolitik, 49, 2750.

Brown, S. and J.G. Sessions (1996): The Economics of Absence: Theory and Evidence. Journal of Economic Surveys, 10, 23-53.

Brown, S. and J.G. Sessions (2004): Absenteeism, 'Presenteeism', and Shirking. Economic Issues, 9, Part 1, 15-20.

Buck, H. (2006): Personalpolitik in konjunkturschwachen Zeiten, Ergebnisse einer Unternehmensbefragung, in: Badura, B., H. Schellschmidt and C. Vetter (eds.): Fehlzeiten-Report 2005, Berlin: Springer, 25-34.

Coles, M.G. and J. G. Treble (1996): Calculating the Cost of Absenteeism. Labor Economics, 3, 169-188.

Daviri, S. V. and S. A. Woods (2006): Uncertified absence from work and the Big Five: An examination of absence records and future absence intentions. Personality and Individual Differences, 41, 359-369.

Doherty, N.A. (1979): National Insurance and Absence from Work. Economic Journal, 89, 5065.

Drago, R. and M. Wooden (1992): The Determinants of Labor Absence: Economic Factors and Workgroup Norms across Countries. Industrial and Labor Relations Review, 45, 764-778.

Frick, B. and M. Malo (forthcoming): Labor Market Institutions and Individual Absenteeism in the European Union: The Relative Importance of Sickness Benefit Systems and Employment Protection Legislation. Industrial Relations.

Hadri, K. (2000): Testing for Stationarity in Heterogeneous Panel Data. The Econometrics Journal, 3, 148-161.

Hesselius, P. (forthcoming): Does Sick Absence Increase the Risk of Unemployment? Journal of SocioEconomics.

Johansson, P. and M. Palme (2002): Assessing the Effect of Public Policy on Worker Absenteeism. Journal of Human Resources, 37, 381-410.

Judge, T. A., J. J. Martocchio and C. J. Thorensen (1997): Five-Factor Model of Personality and Employee Absence. Journal of Applied Psychology, 82, 745-755.

Kauermann, G. and R. Ortlieb (2004): Temporal Patterns in Number of Staff on Sick Leave: The Effect of Downsizing. Applied Statistics, 53, 355-367.

Kenyon, P. and P. Dawkins (1989): A Time Series Analysis of Labor Market Absence in Australia. Review of Economics and Statistics, 71, 232-239. 
Knez, M. and D. Simester (2001): Firm-Wide Incentives and Mutual Monitoring at Continental Airlines. Journal of Labor Economics, 19, 743-772.

Kwiatkowski, D., P. Phillips, P. Schmidt and Y. Shin (1992): Testing the Null Hypothesis of Stationarity against the Alternative of a Unit Root. Journal of Econometrics. 54, 159-178.

Leigh, J.P. (1985): The Effects of Unemployment and the Business Cycle on Absenteeism. Journal of Economics and Business, 37, 159-170.

Leigh, J.P. (1991): Employee and Job Attributes as Predictors of Absenteeism in a National Sample of Workers: The Importance of Health and Dangerous Working Conditions. Social Science and Medicine, 33, 127-137.

McGuire, T. G. (2000): Physician Agency, in: Culyer, A.J and J.P. Newhouse (eds.): Handbook of Health Economics, Vol. 1A, Amsterdam: Elsevier, 461-536.

Riphahn, R. and A. Thalmaier (2001): Behavioral Effects of Probation Periods: An Analysis of Worker Absenteeism. Journal of Economics and Statistics, 221, 179-201.

Schnabel, C. (1991): Strukturelle und konjunkturelle Determinanten des Krankenstandes. Sozialer Fortschritt, 40, 298-304.

Schnabel, C. and G. Stephan (1993): Determinanten des Krankenstandes: Eine Untersuchung mit Betriebs- und Zeitreihendaten. Jahrbuch für Sozialwissenschaft, 44, 132-147.

Shapiro, C. and J.E. Stiglitz (1984): Equilibrium Unemployment as a Worker Discipline Device. American Economic Review, 74, 433-444.

Thalmaier, A. (1999): Bestimmungsgründe von Fehlzeiten: Welche Rolle spielt die Arbeitslosigkeit? IZA Discussion Paper No. 62, Bonn. 